\title{
Conflitos urbanos: grafite e pichação em confronto devido à legislação repressiva
} Urban conflicts: street art and graffiti in confrontation
because of the repressive legislation

Mônica Cristine Fort | Universidade Tuiuti do Paraná (UTP) Pós-doutorado em Comunicação pela Universidade do Estado do Rio de Janeiro (Uerj). Professora e pesquisadora do Programa de Pós-Graduação em Comunicação e Linguagens da Universidade Tuiuti do Paraná (UTP). Vice-líder do Grupo de Pesquisa Interações Comunicacionais, Imagens e Culturas Digitais - Incom.

E-mail: monica.fort@utp.br

Fernando César Gohl | Universidade Tuiuti do Paraná (UTP) Mestre em Comunicação e Linguagens pela Universidade Tuiuti do Paraná. Graduado em Relações Públicas e professor no Centro Universitário de União da Vitória - Uniuv. Especialista em Gestão de Marketing e Negócios (Uniuv) e Artes Visuais, Cultura e Criação (Senac-PR).

E-mail: fgohl@hotmail.com

\section{Resumo}

O presente artigo propóe discutir políticas governamentais em questóes que envolvem o conflito entre pichação e grafite. Para tanto, trata da iniciativa da Associação Comercial do Paraná e da Prefeitura de Curitiba que mobilizaram esforços na repressão à pichação. É possível identificar na codificação da campanha Pichação é crime. Denuncie a reprodução do discurso dominante que tem impacto apenas em parte da sociedade. Empregando conceitos de Hall, Benjamin, Canclini e Martin-Barbero, analisa peças da campanha que associa o pichador a um malfeitor e aborda uma ação de despiche apresentada pelos responsáveis como proposta de criação de uma galeria a céu aberto. Como resultados, aponta que a pichação carrega o gesto comum da ilegalidade e questiona a importância transgressora do grafite na medida em que é absorvido pela cultura dominante.

Palavras-Chave: Comunicação; Pichação; Grafite; Cidades.

\begin{abstract}
This article aims to discuss government policies on issues involving the conflict between legal and illegal graffiti. Therefore, it parts of the initiative of the Parana Trade Association and the City of Curitiba that mobilized efforts to crack down on graffiti. It is possible identify in the campaign Graffiti is crime. Report the dominant discourse that has an impact only on the part of society. Employing concepts of Hall, Benjamin, Canclini and Martin-Barbero, it analyzes parts of the campaign that associates the tagger to a wrongdoer and addresses an action presented by those responsible as a proposed creating a gallery in the open, but that was to hide the graffiti. As a result, it points out that the graffiti bears the common gesture of illegality and it asks the transgressive importance of graphite as it is absorbed by the dominant culture.
\end{abstract}

Keywords: Communication, Graffiti; Cities. 


\section{Introdução}

O grafite e a pichação são manifestações populares contemporâneas que ganharam as ruas das cidades como forma de expressão e comunicação urbana não planejada. Mas um questionamento é recorrente quando se aborda o assunto: pichação e grafite, arte ou vandalismo? É preciso entender tanto a pichação quanto o grafite como formas de comunicação contemporâneas que emanam de sujeitos sociais que não estão alheios ou passivos aos impactos de uma indústria midiática e cultural, pelo contrário, são capazes de se apropriar e subverter seus sentidos numa pluralidade de discursos dialéticos que se espalham pelas cidades nas mais variadas formas. Qualquer pessoa com uma ideia, recursos e coragem para contrariar as regras pode grafitar, mas o simples fato de rabiscar um muro com tinta spray não torna o indivíduo um artista. As culturas do grafite e da pichação, entretanto, são bastante complexas para serem reduzidas sob o rótulo de vandalismo. No caso do grafite que conquistou espaços, aceitação e reconhecimento da sociedade, a repressão é bem menor. Por sua vez, a pichação é duramente combatida em leis, campanhas e também nas ruas.

O presente artigo discute a iniciativa da Associação Comercial do Paraná (ACP) que acredita ser possível, através da repressão e da "educação", erradicar a pintura não autorizada de muros e paredes de Curitiba. Trata-se de uma campanha que, entre outras ações, procura associar a imagem dos pichadores à de vândalos criminosos. Um personagem de animação - um vilão, chamado Zé Sujeira - foi criado para representar o pichador. Utilizando os recursos da publicidade e propaganda como busdoor, outdoor, cartaz, placa, comercial de televisão e rádio, teve a intenção de recrutar a sociedade para a sua causa denunciando as ações de pintura irregular. Além de analisar a campanha, este texto aborda uma ação de "despiche" em uma região central da capital paranaense, etapa da campanha batizada como Pichação é crime. Denuncie. Artistas de rua foram convidados a grafitar áreas de uma rua, mas foram utilizados para apagar pichações que as autoridades consideravam degradar o local.

Considera-se que o grafite é uma linguagem dinâmica que evolui e absorve as mais variadas referências e, gradualmente, vem sendo reconhecida e aceita como uma forma de comunicação urbana da contemporaneidade. Mas justamente essa transformação ressignifica o papel do grafite, deixando dúvidas sobre a sua importância transgressora na medida em que ele é absorvido pela cultura dominante. O estudo emprega conceitos de Stuart Hall, Walter Benjamin, Nestor Garcia Canclini e Jesus MartinBarbero na discussão envolvendo cultura, sociedade e consumo. Também recorre a Bansky , artista de rua "anônimo", que afirma existir guerra ao grafite, mas defende que a poluição visual quem provoca são as empresas, com seus apelos comerciais: "Quem realmente desfigura nossos bairros são as empresas que rabiscam slogans gigantes em prédios e ônibus tentando fazer com que nos sintamos inadequados se não comprarmos seus produtos. Elas acreditam ter o direito de gritar sua mensagem na cara de todo mundo em qualquer superfície disponível, sem que ninguém tenha o direito de resposta" (BANSKY, 2012, p. 10). Os conflitos entre infringir a lei (conforme 
será visto no que diz respeito a pichar), manifestar-se artisticamente em espaços urbanos e exibir apelos publicitários ao ar livre é o que pesquisamos.

\title{
Pichação e grafite
}

O grafite tem origem no movimento de contracultura parisiense de 1968, quando mensagens de caráter político foram escritas nos muros da cidade. O grafite americano saiu das periferias de Nova York e ganhou visibilidade no mundo pelos vagões do metrô daquela cidade. (OLIVEIRA, 2012). Começou como uma escrita de gangues, porém, logo ser tornou mais individual com o surgimento das "tags" ou assinaturas. Os grafiteiros também se agrupam em "Crews" ou grupos de pichadores que se reúnem sob um nome ou sigla, além disso, vários estilos foram criados de letras e, posteriormente, foram incorporados personagens e desenhos cada vez mais complexos.

Pedro Russi Duarte (2010, p. 931) explica que na América Latina, com exceção do Brasil, não há distinção para denominar pichação e graffiti, mesmo existindo ambos os estilos - fala-se graffiti pensando em pichação.

\begin{abstract}
Pichaçôes, correspondem ao tipo de escritura com componentes de elaboração verbal intensos, seu corpus destaca-se no contexto da revolta, herdeira de uma profunda tradição filosófica, política, poética, literária, humorística, irônica (mudar a sociedade a partir daí). Ontologicamente inscrita como: não arte, não desenho, não cultura, despeito, delito, reacionário. Graffiti-Grafite, o início não é muito diferente ao das pichaçôes, mas com acento de resistência formal, melhoramento técnicoestético, comercial, uma domesticação que o transforma em arte (museus, MCM etc.) contrapondo-se à pichaçấo, especialmente a forma do graffiti-hip-hop (um dos elementos da manifestação musical). Destaca-se em imagens plásticas que mudaram o conceito do muro para mural e de cenários fixos para móveis (por exemplo, trens) (RUSSI-DUARTE, in ENCICLOPEDIA INTERCOM, 2010, p. 931).
\end{abstract}

No presente artigo, usaremos a palavra escrita em português considerando o termo grafite para a pintura autorizada (legal) e pichação para a pintura não autorizada (ilegal), conforme citado em legislação específica. Essa diferenciação demonstra que no Brasil o grafite passa por um processo de "institucionalização", com grafiteiros ganhando notoriedade e sendo remunerados para pintar as paredes das cidades, dar palestras e oficinas de grafite. Em outros países, o grafitti é um movimento de contracultura, de natureza ilegal, e os autores são considerados criminosos. A lei $\mathrm{n}^{\mathrm{o}} 12.408$, de 25 de maio de 2011, alterou o art. 65 da Lei $\mathrm{n}^{\circ}$ 9.605, de 12 de fevereiro de 1998, para descriminalizar o ato de grafitar, diferenciando a pichação do grafite da seguinte forma: se existe autorização para a pintura no muro é considerado grafite; se a pintura não foi autorizada previamente é considerada pichação. $\mathrm{Na}$ prática, pichar ou grafitar sem o consentimento do proprietário é crime passível de detenção e multa e, nesse caso, pichação e grafite são exatamente a mesma coisa perante a lei, caracterizados crime. 
Art. 65. Pichar ou por outro meio conspurcar edificação ou monumento urbano:

Pena-detenção, de 3 (três) meses a 1 (um) ano, e multa.

$\int 1^{\circ}$ Se o ato for realizado em monumento ou coisa tombada em virtude do seu valor artístico, arqueológico ou histórico, a pena é de 6 (seis) meses a 1 (um) ano de detenção e multa.

$\int 2^{\circ}$ Não constitui crime a prática de grafite realizada com o objetivo de valorizar o patrimônio público ou privado mediante manifestação artística, desde que consentida pelo proprietário e, quando couber, pelo locatário ou arrendatário do bem privado e, no caso de bem público, com a autorização do órgão competente e a observância das posturas municipais e das normas editadas pelos órgâos governamentais responsáveis pela preservação e conservação do patrimônio histórico e artístico nacional. (LEI $N^{o}$ 12.408, 25 de maio de 2011).

Por meio de leis e incentivos, alguns grupos políticos perceberam que não podem vencer a luta contra o grafite ilegal e estão trabalhando em conjunto com artistas de rua locais. Com a concessão de espaços e apoio financeiro, o poder público encontrou uma maneira de cooperar com grafiteiros, ao invés de ficar gastando constantemente na limpeza dos muros que, certamente, seriam novamente grafitados. Nesse esquema, alguns artistas renomados são apoiados e ganham espaço para se expressar com seus desenhos em paredes pré-determinadas. Os resultados são murais sobre os quais, dificilmente, outros grafiteiros vão pintar e que acabam incorporados na paisagem urbana. Dessa forma, o grafiteiro realiza o seu trabalho, as prefeituras economizam com a limpeza dos muros e melhoram sua imagem junto aos jovens, demonstrando apoio a sua arte. Inserir o grafite no movimento denominado Arte Urbana, que conta com técnicas como a aplicação de adesivos, uso do estêncil (molde vazado) e cartazes, ajuda a atribuir-lhe um caráter artístico e diferenciá-lo da pichação.

Mas, pesquisadores como Franco (2009) e Soares (2012) identificaram em pichadores e grafiteiros uma busca em constituir identidades, cooperação, autoafirmação e uma prática de lazer de grupos que não se enquadram necessariamente ao que o Estado espera de um cidadão típico, obediente de suas obrigações. Considerados criminosos, esses grupos têm dificuldade em se organizar em relação ao poder dominante e são ainda mais afastados da participação do cotidiano da cidade. A busca pelo risco e a transgressão de regras são fatores motivadores. Segundo relatos citados pelos pesquisadores, muitos pichadores deixariam de pichar caso isso não fosse mais considerado ilegal.

De uma maneira ou de outra, todas as formas de grafite e de pichação continuam a coexistir em muros das cidades, mas o grafite é mais aceito e tolerado pela sociedade e pelo governo por estar associado ao movimento de arte urbana e ter artistas figurando o cenário internacional, mesmo que muitos deles tenham iniciado ou pratiquem até hoje a pichação, aquela ilegal. Como exemplo, cita-se a "mistura" de pichação e grafite da dupla Os Gêmeos (ver Figura 1). Observa-se que foi apagada apenas a mensagem "Vinagre é crime" que estava escrita "na forma" de pichação durante o período das manifestações populares ocorridas em junho de 2013 no Brasil. 

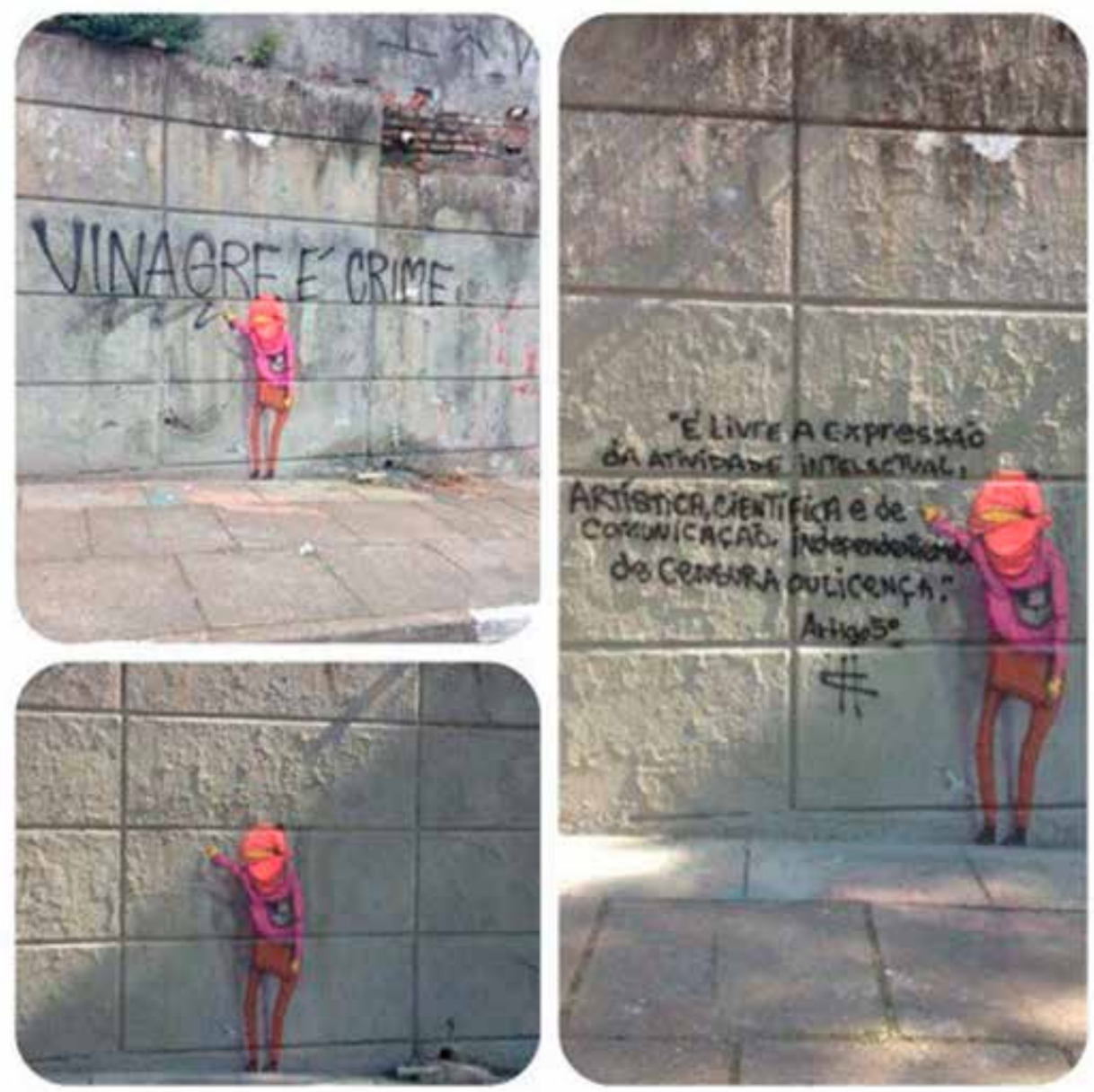

Figura 01 - Pichação dos artistas “Os Gêmeos”: Veja São Paulo ${ }^{4}(2013)^{3}$

Em nota, a Prefeitura de São Paulo alegou um equívoco na identificação da intervenção, confundindo a frase como uma pichação que não fazia parte da obra. Posteriormente, os autores picharam no mesmo lugar o artigo 5․ da Constituição Federal (1988): "É livre a expressão da atividade intelectual, artística, científica e de comunicação, independentemente de censura ou licença". Mesmo sendo grafite, o desenho também foi feito sem autorização, portanto é ilegal e criminoso. Por este exemplo, fica visível a estreita relação e confusão entre grafite e pichação que há no país e que foi tão bem demonstrada pela dupla Os Gêmeos nessa intervenção e em outras nas quais protestavam contra as ações da lei Cidade Limpa que existe em São Paulo.

\section{Arte urbana}

Não é tão simples promover o grafite na indústria da arte, por ter como princípio a pintura em espaços públicos, geralmente em larga escala e em superfícies imóveis, torna-se difícil sua exibição e venda em galerias. Desde a virada do milênio, surgiram nas grandes cidades, "museus a céu aberto" de Arte Urbana que estão atraindo cada vez mais atenção e dinheiro. Os artistas utilizam as cidades como suporte para criar e expor seu trabalho e lucrar com isso, criando uma marca e vendendo suas produções. A institucionalização do grafite contraria sua origem marginal de crítica à sociedade do consumo, ao sistema capitalista de produção e à desvinculação 
do valor comercial do valor artístico, gerando questionamentos e embates internos no próprio movimento, que não considera como grafite aquilo que é realizado de forma autorizada.

Benjamin $(1936,2000)$ abre uma discussão sobre arte e modernidade capitalista, questionando a autenticidade, o caráter único da obra de arte e se a originalidade estaria abalada pela reprodução técnica, em série, abalando assim a sua aura. Apesar de parecer otimista em alguns momentos, como em relação ao cinema e seu possível uso e controle popular, o autor vê a decadência da aura definida como única aparição de uma realidade longínqua, por mais perto que ela possa estar. Sendo os critérios de autenticidade não mais aplicáveis à produção artística, a função da arte estaria subvertida, não sendo mais concebida em uma práxis ritualística, mas numa práxis política. Podemos encontrar no pensamento de Benjamin (1936, 2000, p. 250) um paralelo nas práticas de pichação e grafite, quando ele refere que "...a massa é a matriz de onde brota, atualmente, todo um conjunto de novas atitudes em face da obra de arte. A quantidade tornou-se qualidade”. Sobre a prática de reprodução de seus desenhos, por exemplo, Banksy (2012, p. 239) diz: "Com uma lata comum de tinta de $400 \mathrm{ml}$ você faz até 50 estêncis formato A4. Isso significa que, da noite para o dia, você pode se tornar incrivelmente famoso/impopular numa cidade pequena por apenas 10 libras".

O grafite e a pichação podem criar experiências impactantes e sensibilizar, despertando, na relação com esses objetos, sentidos adormecidos, novos olhares e novas associações de memórias. Georges Didi-Huberman (1998, p. 147) faz uma reinterpretação do conceito de aura, afastando a questão de culto (como crença) e colocando a relação entre as distâncias do que "vemos e do que nos olha" como a essência da aura que "seria, portanto, como um espaçamento tramado do olhante e do olhado, do olhante pelo olhado". Dessa forma, recupera o caráter dialético do perto-longe, assim como vê, mesmo em situações do cotidiano, a possibilidade da existência da aura, propondo uma postura de "inquietar" o nosso ver diante da imagem.

Ao privilegiar a análise nas mediações culturais, Martín-Barbero (1997) consegue abarcar toda gama de conflitos, contradições e formas de dominação e transformação do meio social. Falando especificamente da pichação e do grafite, temos nas paredes da cidade um meio de propagação e reprodução de elementos culturais, assim, "o eixo do debate deve se deslocar dos meios para as mediações, isto é, para as articulações entre práticas de comunicação e movimentos sociais, para as diferentes temporalidades e para a pluralidade de matrizes culturais" (MARTINBARBERO, 1997, p. 258). O autor destaca:

O valor do popular não reside em sua autenticidade ou em sua beleza, mas sim em sua representatividade sociocultural, em sua capacidade de materializar e de expressar o modo de viver e pensar das classes subalternas, as formas como sobrevivem e as estratégias através das quais filtram, organizam o que vem da cultura hegemônica, e o integram e fundem com o que vem de sua memória histórica (MARTIN-BARBERO, 1997, p. 15). 
Ao analisarmos essas manifestações, não apenas pela perspectiva reducionista do vandalismo, mas partindo da sociedade e da cultura, temos uma ampliação de análise que permite a construção de caminhos diversos, principalmente na relação entre cultura e comunicação de massa e na reprodução ou resistência aos sistemas de dominação, revelando um caráter político importante no gesto de pichar e grafitar.

\section{Repressão à pichação}

Em janeiro de 2013, foi lançada a campanha institucional Pichação é crime. Denuncie, uma iniciativa da Associação Comercial do Paraná (ACP) em conjunto com a Prefeitura Municipal de Curitiba e diversos órgãos públicos e privados. Foram implantadas medidas como: mudança na lei que elevou a multa para os pichadores pegos em flagrante ; nova regulamentação para a venda de tinta spray para menores de 18 anos; campanhas publicitárias de mobilização da opinião pública; palestras; eventos de "despichação" de áreas da cidade.

De acordo com a Guarda Municipal da capital paranaense, em 2012, perto de 400 pessoas foram detidas envolvidas com a pichação, sendo que metade era formada por maiores de 18 anos de idade. Informações divulgadas no site da $\mathrm{ACP}$ referentes àquele ano indicam que a pichação teria causado prejuízos superiores a $\mathrm{R} \$ 1$ milhão para a administração pública em 2012. As notícias publicadas pela ACP prestam contas de dois anos após a implantação do projeto, que segundo eles é um divisor de águas na história de repressão da pichação. Os dados da Guarda Municipal mostram um aumento expressivo na quantidade de denúncias e flagrantes num primeiro momento e, posteriormente, a queda substancial desses números, o que indicaria o sucesso do projeto na repressão dos pichadores.

Quem é flagrado pichando pode receber multa de $\mathrm{R} \$ 1.693,84 \mathrm{e}$ quem é reincidente pode ser enquadrado por associação criminosa e pegar até quatro anos de prisão. Os estabelecimentos que vendem tinta spray de forma irregular pagam multa de $\mathrm{R} \$ 4.234,60$, em caso de reincidência $\mathrm{o}$ valor sobe para $\mathrm{R} \$ 8.469,21$ e na terceira punição o alvará de funcionamento do estabelecimento é cassado. Entretanto, pelos dados divulgados, apenas três homens que foram surpreendidos juntos pichando, no dia 23 de outubro de 2014, são reincidentes e uma única empresa recebeu multa pela venda irregular de tinta spray até o final de 2014.

A campanha institucional foi realizada pela agência curitibana TXPlublitex Comunicação e figura entre os cases mostrados no site da empresa.

\begin{tabular}{|l|l|}
\hline \multicolumn{2}{|c|}{ Ficha Técnica da Campanha "PICHAÇÃO É CRIME" } \\
\hline Cliente: & Associação Comercial do Paraná \\
\hline Projeto: & Pichação é Crime. Denuncie. \\
\hline Diretor de criação: & Luiz Teixeira Oliveira Jr. \\
\hline Redação: & Johnny Fragoso \\
\hline Direção de arte: & Michael Catunda \\
\hline Atendimento: & Luiz Teixeira Oliveira Jr. \\
\hline Mídia: & Dayane Ganz \\
\hline Assistente de atendimento: & Mariana B. Hanneman \\
\hline
\end{tabular}

Fonte: TX-Plublitex Comunicação 
Nas peças publicitárias, além da frase Pichação é crime. Denuncie, foi adicionada a frase: "Não deixe que vândalos sujem nossa cidade". O diretor de arte Michael Catunda (2013), em seu site pessoal, enfatiza "Vamos deixar Curitiba novamente bonita". Catunda também postou sugestões de aplicação da peça publicitária (Figura 02) em adesivos, camisetas, banners, lápis e no mobiliário urbano.

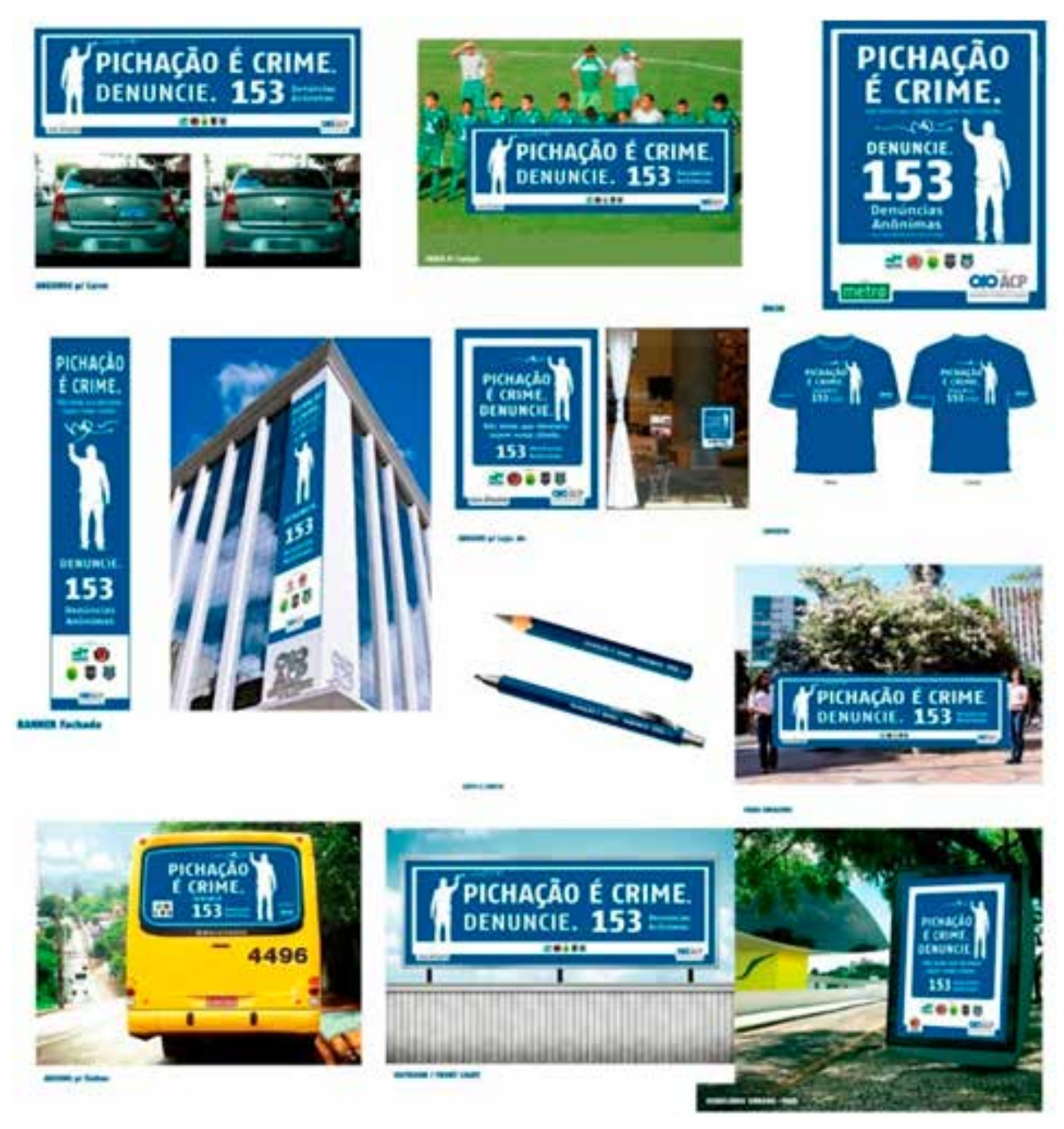

Figura 02 - Aplicação da campanha - Fonte: Catunda, 2013.

A frase "Pichação é crime" consta em todas as latas de spray vendidas no Brasil, uma obrigatoriedade imposta pelo art. $4^{\circ}$ da Lei $n^{\circ} 12.408 / 2011$ e que foi aproveitada pela campanha. A frase "Não deixe que vândalos sujem nossa cidade" demonstra os dois argumentos que nortearam o tom da campanha, o vandalismo e a sujeira. Pode-se dizer que assim como a pichação, essa campanha institucional também "sujou" com sua mensagem a paisagem da cidade, utilizando espaços destinados à propaganda. Ampliando ainda mais a discussão, é possível estender a polêmica da poluição visual que os pichadores provocam e indagar: A cidade é para as pessoas ou para as empresas?

Define-se poluição visual como o excesso de elementos ligados à comunicação (cartazes, anúncios, propagandas, banners, totens, placas etc.) dispostos em ambientes urbanos, especialmente em centros comerciais e de 
serviços (SEED/PR, 2015). Para disciplinar o tema e evitar tal poluição, em São Paulo, a prefeitura instituiu a lei $\mathrm{n}^{\circ}$ 14.223, em 26 de setembro de 2006, que estabeleceu um conjunto de normas para o uso publicitário do espaço urbano e está explicada da seguinte forma:

A Lei Cidade Limpa significa a supremacia do bem comum sobre qualquer interesse corporativo. Sua aplicação permitirá a São Paulo diminuir a poluição visual que há tantos anos prejudica nosso bem-estar e promover uma melhor gestão dos espaços que, por concessão pública, poderão ter mobiliário urbano com propaganda. Mais do que um texto com proibiçôes, a lei é um meio para tornar São Paulo ao mesmo tempo mais estruturada e acolhedora. (SÃO PAULO, 2015)

Já na capital paranaense, o decreto $\mathrm{n}^{\circ} 402$, de 08 de maio de 2014, dá nova regulamentação à Lei Municipal $n^{\circ} 8.471$, sobre publicidade ao ar livre, e pretende ordenar a poluição visual em Curitiba, ampliando o controle do Estado na forma como as empresas anunciam suas marcas e produtos, facilitando assim a captação de dinheiro dos empresários para os cofres públicos.

Bourdieu e Passeron (1982, apud ALMEIDA, 2005) empreenderam estudos pioneiros sobre a sociologia das práticas de cultura. Os autores relacionam esses estudos à necessidade humana de produzir sentido e estabelecer relações com seus grupos. Para ele, a construção social da realidade é fundamentada nas articulações de sentido que os indivíduos estabelecem uns com os outros. As práticas de cultura são espaços de diálogo entre o indivíduo e a sociedade através de uma multiplicidade de símbolos e valores atribuídos a eles ao longo da história. A dialética da produção, reprodução e renovação da ordem é própria da realidade do social, e o jogo entre a manutenção ou subversão das estruturas sociais de dominação é objeto de estudo da sociologia em que a mídia desempenha um papel catalizador na circulação dos discursos de hegemonia.

\section{Codificando a pichação}

$\mathrm{Na}$ segunda etapa da referida campanha institucional contra a pichação em Curitiba, para tornar as peças publicitárias mais lúdicas, pedagógicas e simpáticas a crianças e adolescentes foi criado o personagem Zé Sujeira (Figura 03), que associa a figura do pichador à de um criminoso, sujeito do qual devemos manter distância e que surge furtivamente para emporcalhar a cidade. Esse personagem foi inspirado em outro, o Sujismundo (Figura 04), animação famosa da década de 70 criada pelo cartunista Ruy Perotti por encomenda do Governo Federal para conscientizar a população brasileira sobre higiene pessoal e limpeza das cidades. A campanha daquela época tinha como slogan a frase: "Povo desenvolvido é povo limpo".

Sobre a criação do personagem Zé Sujeira, o presidente da ACP, Edson José Ramon, deu o seguinte depoimento à Rádio Prefeitura (2014): "Nós queremos ver que, a criança ou adolescente, que ele perceber esse personagem, ele pense: 'Olha, aí vem o Zé Sujeira, vamos sair dessa. Ele vem emporcalhar a cidade, os nossos muros e as nossas casas'. É mais ou menos essa a ideia". 

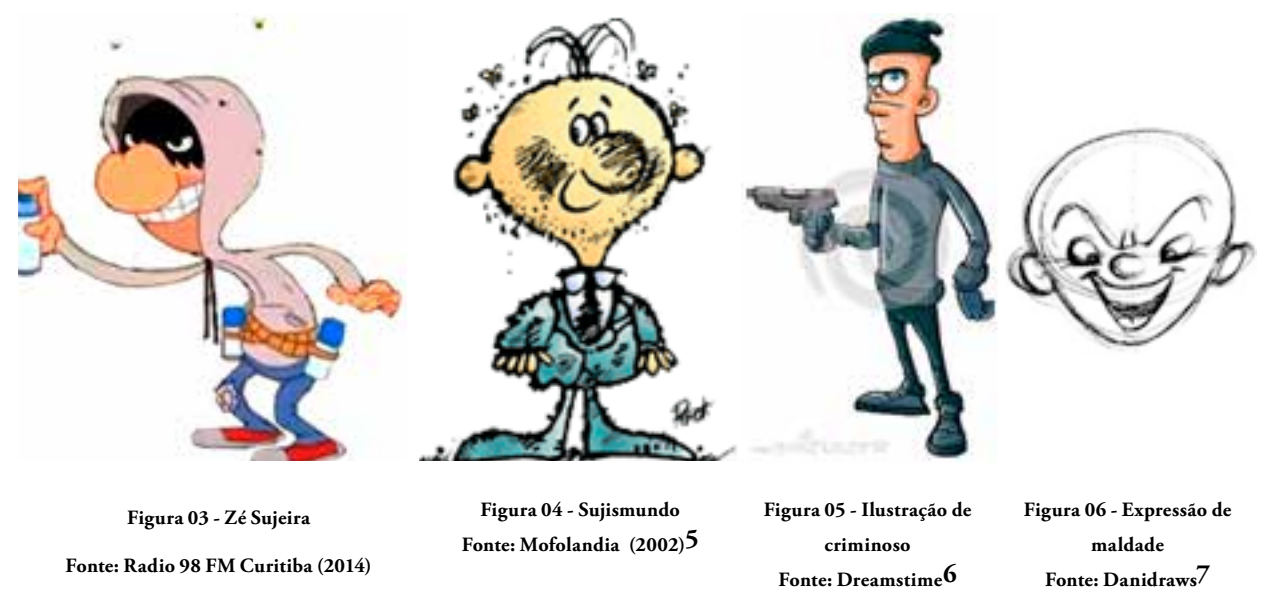

Pode-se observar que o personagem Zé Sujeira herdou as moscas do Sujismundo (Figura 04). Na realidade, assemelha-se a um ladrão, tem fisionomia de viláo e está com a identidade encoberta pelo gorro da blusa e um tipo de máscara nos olhos. Sua expressão facial é de maldade (Figura 05). A calça de Zé Sujeira está rasgada e moscas rondam sua cabeça, o que pode demonstrar falta de higiene pessoal e despreocupação com a aparência. Ele tem uma lata de spray na mão e outras duas amarradas na cintura, como um bandido (Figura 06), um justiceiro à margem da lei com o spray como arma. Por outro lado, é interessante observar o poder que um cidadáo comum tem de protestar por meio de mensagens nos muros da cidade feitas com uma lata de spray, o que pode ser considerado uma arma contra um governo repressor e uma mídia centralizada nas mãos de poucos e alinhada a interesses que nem sempre refletem os da sociedade. Uma campanha institucional que, com a intençáo de "educar", cria um personagem que apela ao público infanto-juvenil, na tentativa de incutir normas e conceitos.

A construção desse discurso faz sentido a uma parte da sociedade, e pode fazer com que esses jovens, futuramente, sintam-se enganados quando pesquisarem mais sobre o assunto e descobrirem que a pichação é mais complexa que a simples argumentação de vandalismo e sujeira. Pichar não pode, mas é possível persuadir crianças e adolescentes com propaganda institucional, utilizando um personagem de animação totalmente descolado da realidade. Onde alguns veem sujeira, outros enxergam arte.

Essas diferentes interpretaçóes podem ser compreendidas a partir de pressupostos de Stuart Hall (2003). Refutando a linearidade das pesquisas em comunicação de massa baseadas no modelo emissor, mensagem, receptor, o autor propóe um modelo ampliado, circular para analisar a complexa relação do processo de codificação e decodificação, dividindo nos momentos de produção, circulação, distribuiçáo/consumo, reprodução (HALL, 2003, p. 387). A produção da mensagem deve obedecer às "regras de linguagem" e códigos profissionais estabelecidos pelas formas audiovisuais e auditivas do discurso televiso. A produção então torna-se um momento significativo no processo que dá forma a um discurso, que segue um fluxo com o objetivo de produzir sentido e concretizar o "consumo" da mensagem. 
Aproveitando a analogia de O capital, esse é um "processo de trabalho" no modo discursivo. A produção, nesse caso, constrói a mensagem. Em um sentido, então, o circuito começa aqui. É claro que o processo de produção não é isento de seu aspecto "discursivo": ele também se constitui dentro de um referencial de sentidos e ideias: conhecimento institucional, definiçóes e pressupostos, suposiçóes sobre a audiência e assim por diante delimitam a constituição do programa através de tal estrutura de produção. (HALL, 2003, p. 389).

Hall também cita a importância do paradigma semiótico para o estudo do conteúdo televisivo e de seu discurso audiovisual, que por representar a realidade tem grande efeito ideológico, tamanha naturalizaçáo com que incorporamos essa linguagem e ao explicar a uso entre denotação e conotação, Hall (2003, p. 395) argumenta que "Muito poucas vezes os signos organizados em um discurso significarão somente seus sentidos 'literais', isto é, um sentido quase universalmente consensual".

Na peça publicitária audiovisual de 30 segundos produzida para a televisão, observam-se questôes mais complexas. Abaixo está a transcrição do áudio e, na Figura 07, apresenta-se um dos frames que revela sinais importantes da criaçáo:

Menina: Xi, lá vem o Zé Sujeira.Menino: Ah, eu não quero falar com esse sujeito que vive pichando por ai.

Menina: Além de emporcalhar a cidade, ele tá cometendo um crime.

Adulto: Olha, vocês têm razão. Pichação é crime e todos podem denunciar. Além de prisão, a multa é alta.

Voz Off: Pichação? Aqui não, Zé Sujeira. Pichação é crime. Denuncie, ligue 153. Uma iniciativa da Associação Comercial do Paraná parceria da Prefeitura de Curitiba e seus apoiadores.

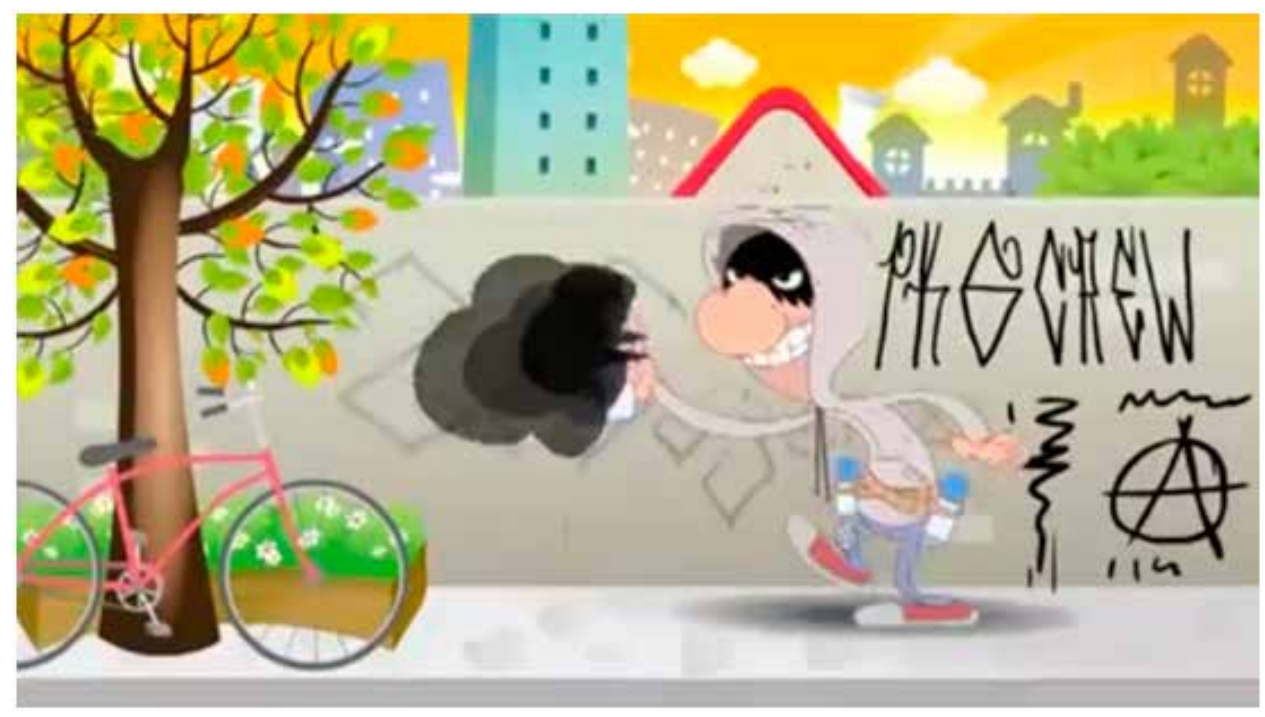

Figura 07 - Frame do spot - Fonte: Radio98FM Curitiba (2014)

$\mathrm{Na}$ propaganda, é possível ver rapidamente a atuação do pichador Zé Sujeira. Ele está deixando sua assinatura no muro, sua tag, escrevendo seu apelido como uma marca, usando um tipo de letra estilizado. Pode-se identificar também a escrita PKG CREW, na qual a palavra Crew serve para identificar os grupos ou famílias de pichadores e grafiteiros e, logo abaixo, há o símbolo que 
remete ao movimento anarquista. Nota-se que a agência empreendeu pesquisa sobre o assunto para criar o comercial, reconhecendo, através dos símbolos utilizados, algo além do vandalismo e da sujeira. Mesmo nessa curta animação, observam-se indivíduos e grupos que se comunicam através de códigos nos muros, que têm linguagem e ideologia próprias, representando uma cultura popular de rua com padróes estéticos diferentes e diferentes formas de representá-los.

Essa ordem que se busca para a cidade não é encontrada na política, de acordo com Ramos e Santos (2007, p. 22): "Política é ruído, conflito. Política está muitas vezes próxima do caos. A Política é o terreno dos homens, com tudo que de bom e de mau sua humanidade lhes dá", os autores também citam os aparelhos privados de hegemonia "[...] Empresa e a Mídia são os principais aparelhos privados de hegemonia; este, a Mídia, uma forma singular daquela, a Empresa” (RAMOS; SANTOS, 2007, p. 39)

Segundo Gramsci (2000, apud ALMEIDA, 2011, p. 121), "a hegemonia se constrói a partir da sociedade civil e suas diversas instituiçóes, mas tem no Estado um instrumento indispensável para a sua realização, consolidação e reprodução", agindo numa combinação de coerção e consenso em que a mídia tem papel decisivo na construção de discursos formadores de uma representação social do estado. A mídia ganha importância como arena de debate e disputa de ideologias na sociedade, entretanto, quando os meios de comunicação se configuram em monopólios ou estấo nas mãos de poucos grupos, a democracia e a comunicação são abaladas. Há registros dos meios de comunicação, aliados da campanha, exibindo notícias de pichadores que cometeram roubos ou foram presos por porte de drogas. O "policiamento", termo apresentado aqui como a fiscalização não só por parte das autoridades, mas também de cidadãos convidados a denunciar o "vandalismo", também se encontra na internet, monitorando as redes sociais na busca da identificação e punição de pessoas, através da quebra de sigilo dessas redes e dos provedores de acesso.

É preciso entender a pichação e o grafite como formas de comunicação contemporâneas que emanam de sujeitos sociais que não estão alheios ou passivos aos impactos de uma indústria midiática e cultural, pelo contrário, são capazes de se apropriar e subverter seus sentidos numa pluralidade de discursos dialéticos que se espalham pelas cidades nas mais variadas formas. Canclini (2003) considera que as investigaçôes nessa área ignoravam os aspectos socioculturais do receptor, atribuindo aos meios de comunicação o protagonismo da comunicação e manipulação da audiência.

Ao analisar essas manifestaçôes, não apenas pela perspectiva reducionista do vandalismo, mas partindo da sociedade e da cultura, há uma ampliação de análise que permite a construção de caminhos diversos, principalmente na relação entre cultura e comunicação de massa e na reprodução ou resistência aos sistemas de dominação, revelando um caráter político importante no gesto de pichar e grafitar. Banksy (2012, p. 10) defende:

Um muro sempre foi o melhor lugar para divulgar seu trabalho. As pessoas que mandam nas cidades não entendem o grafite porque acham que nada tem o direito de existir se não gerar lucro, o que torna a opiniáo delas desprezivel. Essas pessoas dizem que o 
grafite assusta o público e é um símbolo do declínio da sociedade. O perigo, porém, só existe na cabeça de três tipos de indivíduos: políticos, publicitários e grafiteiros.

Banksy é considerado o artista de rua "anônimo" mais famoso da atualidade, e pintou paredes, sem autorização, de várias cidades do mundo, inclusive em Nova York onde é considerado criminoso devido à política de repressão ao grafite, que faz parte da repressão à violência adotada com a "Teoria das Janelas Quebradas" ou Broken Windows Thesis, idealizada pelos professores criminologistas George L. Kelling e James Q. Wilson nos anos 1980, aponta que se a janela de um prédio é quebrada e não é logo reparada, em breve, todas as outras janelas serão quebradas (OLIVEIRA, 2013). A análise da dupla é de que o crime é resultado da desordem, portanto a manutenção da ordem está imediatamente ligada à prevenção de crimes. Então, combatendo e punindo pequenos delitos, também se previne que a criminalidade avance.

Essa teoria foi usada como fundamento para uma grande ação de combate ao crime na cidade de Nova York na década de 1990 e da tolerância zero ao grafite. Apesar de ser considerada um sucesso na história do combate ao crime, a política adotada fez com que as comunidades negra e hispânica sofressem com a discriminação de décadas de desconfiança com a ação policial stop-and-frisk (prender e fichar uma pessoa simplesmente por sua aparência). (FREITAS NETO, 2007). Muitos críticos afirmam que parte dela a discriminação social e o racismo de policiais norte-americanos que num regime de tolerância zero aos pequenos delitos transformam em alvo preferencial os pobres, os negros e os hispânicos. Os questionamentos à teoria voltaram à tona após a mídia divulgar casos de negros que foram mortos por policiais, despertando revoltas e manifestações em suas comunidades.

\section{Despiche com grafite}

Do ponto de vista político, mesmo que a batalha contra a pichação já comece perdida, pois a pichação tem resistido historicamente a todas as medidas repressoras, campanhas como a adotada na capital paranaense só favorecem as instituiçóes e seus representantes, seja dando visibilidade e notoriedade. Além da campanha institucional que associou o pichador a um malfeitor, Curitiba também adotou um projeto de revitalização. O Projeto Arte Urbana - Memórias de Curitiba contou com cerca de 20 grafiteiros para pintarem as portas de aço de estabelecimentos comerciais da rua São Francisco. Essa também foi uma iniciativa da Associação Comercial do Paraná (ACP), em parceria com a prefeitura de Curitiba e executada pela produtora de arte Mucha Tinta com patrocínio da Sanepar, Companhia de Saneamento do Paraná .

Observa-se, em notícias publicadas no jornal paranaense Gazeta do Povo que a ação de pintura, realizada em 23 de junho de 2013, visava criar uma galeria de arte a céu aberto em uma região do centro histórico da cidade. Foram selecionados os títulos de quatro reportagens, dos dias 20, 23 e 24 de junho e 03 e julho de 2013. São eles: Projeto vai criar galeria a céu aberto no São Francisco, Thomas Rieger ; Artistas fazem despiche da Rua São Francisco: 
arte substitui pichaçóes nas portas das lojas do comércio local, Lana Canepa ; Despiche chega à rua São Francisco, Lana Canepa ; Grafite vence a pichação e propicia galeria a céu aberto, Raphael Marchiori . As informaçóes exaltam o projeto associando a ideia a algo positivo. No entanto, depoimentos de grafiteiros coletados no documentário Expressão da rua, produção acadêmica de Liege Scremin e Matheus Gasparin (2014), demonstram desconforto de grafiteiros com essa proposta de despiche.

Dimas - Interventor de stencil - Motion Layers / Mucha Tinta

Aos 13’42”: Tá rolando uma campanha aí, né? De pichação é crime e tal, que é da própria Associação Comercial, que ironicamente financiou o projeto lá da São Francisco.

DG Pichador - Cretinos

Aos 16'41": O cara chega, o grafiteiro falar com pichador, até vai, eu sou um, que se chegar pra mim e falar eu sou da prefeitura, eu não ligo. Agora chegar, meter tinta por cima, sem pedir não a autorização, mas dar satisfação, eu sou a favor do cara voltar e meter tinta por cima do grafite, porque eu acho que é falta de respeito isso daí.

Aos 17'05”: Eu fui lá, analisei e vi que a porta é de um amigão meu. Eu fui lá pedir pra ele. Ele falou: não cara, ainda bem que é você, se fosse outro, eu ia pichar em cima.

Café - Grafiteiro - UtopiaAos 14'27”: A ideia foi, 'é, vocês vão fazer um desenho relacionado à história de Curitiba'.

Aos 15'40": Quando a gente estava lá pintando veio a história de que era o despiche.

Gislaine C. - Comerciante da rua São Francisco

Aos 14'48": A rua tava muito feia.

Aos 15'10": Quando eles terminaram de colocar as plaquinhas do lado de lá, quando elas vieram pra cá já tinha uma plaquinha lá pichada, e eles nem tinham feito o trabalho ainda. Ai, fui, peguei um querosene, emprestei pra ela, foi lá, limpou. Mas no mesmo dia já... isso com o pessoal aqui fazendo entrevista, fazendo o trabalho, eles já 'tavam pichando.

Aos 17'27": Os pichadores, é, eles ficaram, acredito que indignados por tamparam o trabalho deles, né, e eles vieram e colocaram o trabatho que já estava embaixo.

Michael Devis - Grafiteiro e Proprietário da Capsula Graffiti Shop

Aos 16'04": Acho que é uma campanha de puro marketing da 


\begin{abstract}
Associação Comercial do Paraná, porque eles usam de suporte públicos, gratuitamente, e usam de vários mecanismos de publicidade, gratuitamente.

Elizabeth Prosser - Pesquisadora - Faculdade de Belas Artes do PR

Aos 16'25": Então se você quer que aconteça um despiche, não faça uma campanha despiche Curitiba, ela não funciona.

Willians Batista - Comerciante da sua São Francisco
\end{abstract}

Aos 17'15": Pelo fato do artista não ter pedido autorização, eles vieram e picharam por cima do grafite.

Olho Wodzynski

Aos 17'52": Tem coisas que são válidas, a rua São Francisco, eles sabem bem claro que existia a possibilidade de pichar de volta por cima. $O$ grafite não vai tapar a pichação, quem quiser, vai lá e pinta por cima.

A partir de Hall (2003) compreende-se que a produção de significado depende da troca entre codificador-produtor e decodificador-receptor e, portanto, podem ocorrer mais ou menos "distorções" por conta da falta de equivalência entre os dois lados, resultando em graus maiores ou menores de compreensão da mensagem. Pelos depoimentos coletados para o documentário, é possível perceber que a pichação não foi vencida pelo grafite como anunciado, pois ela nunca deixou de acontecer, nem durante e nem após o evento. Os grafiteiros relatam que foram chamados para mostrar a sua arte, valorizar o grafite, e não para um evento de despiche e que souberam, durante o evento, que se tratava de um movimento "antipichação", o que gerou relativo mal-estar em alguns grafiteiros que participaram do projeto.

Isso fica claro ao considerar o que Canclini (2006) comenta como uma conversão dos patrimônios simbólicos tradicionais aos mercados econômicos. O autor afirma que já não é possível considerar os membros de cada sociedade como elementos de uma cultura homogênea com uma identidade distinta e coerente. As relações entre cidadania, globalização e consumo são exemplos da diversidade de produtos culturais aos quais o cidadão tem acesso, o que enfraquece referências e influências mais próximas a ele, modificando formas de consumir cultura no que diz respeito à percepção de pertencimento de nação e de construção da identidade. Para o autor, os processos de negociação constituem recursos chaves para se redefinir o que é identidade, classe e popular, mais em uma dimensão cultural do que política. Refere-se às questões da vida cotidiana e na interação entre políticas culturais e receptores populares.

A pichação, como fenômeno efêmero de comunicação urbana, deixa marcas na sociedade e no ambiente, marcas que podem ser acessadas por outros, possibilitando uma transição do efêmero para o durável a partir da interação, da relação entre a pessoa e o ambiente: 
...isso significa que a "experiência" exige a mobilização sensorial e fisiológica do corpo humano; é ao mesmo tempo uma atividade prática, intelectual e emocional; é um ato de percepção e, portanto, envolve interpretação, repertório, padröes; existe sempre em função de um "objeto", cuja materialidade, condiçôes de aparição e de circunscrição histórica e social não são indiferentes. (GUIMARÃES; LEAL, 2007, p. 6).

As cidades estáo sempre mudando. O grafite e a pichaçáo acompanham esse movimento. São registros de pessoas que ali estiveram, deixaram a sua marca, sua arte, seu pensamento. Marcas efêmeras com camadas de tinta sobre uma superfície e que podem desaparecer para sempre, mas que deixam um rastro de vestígios por onde passam. Assim como toda guerra produz um rastro de destruição, a pichaçáo deixa o seu rastro estético, político e social. Segundo Braga (2010, p. 83), isso "corresponde a dizer que não é a experiência meramente psicológica que é "estética", mas sua relação interacional ou comunicativa, o compartilhamento - o trabalho de objetivação da emoção sentida. Trabalho que, por sua vez, como expressão de relação entre pessoa e situação, é ainda "experiência vivida".

Contra o argumento da depredação e da decadência de um lugar em que o grafite, assim como uma janela quebrada pode desencadear, Banksy (2012, p. 132), de forma irônica, publicou um e-mail que reclama justamente do efeito contrário:

Carta recebida pelo site do Banksy

Não sei quem é você ou quantos de você existem, mas estou escrevendo para pedir que pare de pintar no lugar onde moramos. Especialmente na rua xxxxxx, em Hackney. Eu e meu irmão nascemos aqui e moramos aqui nossas vidas inteiras, mas nos últimos tempos tantos yuppies e estudantes estão se mudando para cá que não temos mais dinheiro para comprar uma casa no lugar em que crescemos. Seus grafites são sem dúvida parte do que faz esses babacas acharem que nosso bairro é descolado. Você obviamente não é daqui e, depois que os preços dos imóveis subirem, é possivel que você vá para outro lugar. Faça um favor para todos nós e vá pintar suas coisas em algum outro lugar, como Brixton.

Daniel (sobrenome e endereço não incluidos)

\section{Considerações finais}

A pichação ou o grafite não autorizado dos muros não são bem compreendidos pela sociedade e por autoridades que demonstram ter uma visão reduzida da questão, encarando movimento de forma judicial, como vandalismo ou sujeira, e tratando do assunto sem discussão, com propaganda ideológica e repressão. Dessa forma, são afastados outros pontos de vista que devem fazer parte da conversa sobre o futuro das cidades. Nessa discussão, entram temas como arquitetura e urbanismo, publicidade e propaganda, liberdade de expressão, preservação de patrimônio, poluição visual, só para citar alguns. A subordinação da ação política e a espetacularização pela mídia reduzem a importância de manifestações públicas e de massa, de instâncias em que negociações podiam ser efetuadas na redefinição do que é identidade, classe e popular (CANCLINI, 2006). 
O pichador é um sujeito multifacetado, picha por adrenalina, para pertencer a um grupo, para sua autoafirmação, para demarcar território, para protestar politicamente, não quer ser enquadrado em normas, então parece inocente o pensamento de que a pichação possa ser erradicada por uma campanha. Aliás, deve-se mesmo erradicar a pichação? Talvez, para o pichador, quanto mais dificuldades forem impostas entre o spray e o muro, maior será o desejo de deixar o seu recado nele, então não parece ser possível deixar de ver pessoas, comunicação e resistência por trás de cada pichação.

Ao considerar que há uma espécie de obrigatoriedade de se ver publicidade e propaganda pintada em cada pedaço da cidade, seja na forma de busdoor, outdoor, cartaz, placa, fachada, ou nas marcas impressas em cada produto que se tem ao alcance das mãos, e nas exaustivas repetições de comerciais de televisão para convencer o público-alvo a comprar isso ou aquilo, ter esse ou aquele comportamento, não se poderia considerar também a propaganda da Associação Comercial do Paraná como poluição visual institucional ao ser atingido por ela?

Algumas iniciativas, como a lei da Cidade Limpa, em São Paulo, e a alteração da lei que descriminaliza o grafite são marcos importantes, pois mostram que é possível mudar o atual cenário, onde o universo corporativo domina o visual das cidades e ampliar o debate envolvendo as demandas da população nas decisões sobre o uso do espaço urbano. Mas, deve-se considerar, também, que a pichação política, ideológica ou de protesto até a pichação mais egoísta ou com a simples intenção de conspurcar a cidade, carrega o gesto comum da ilegalidade, a ação de fazer algo que é essencialmente fora da lei.

A sociedade de classes carece de democracia, mas o senso comum impede que se veja isso. Com a pichação, esse nervo fica exposto, mostrando a força das instituições em manipular a cultura, principal campo de batalha para a manutenção do seu domínio. Se as autoridades estão buscando uma batalha contra a pichação, talvez o que resuma melhor o sentimento de "revolta contra o sistema" é o que se observa na frase repetida em diversos muros, como um slogan, "Eu pixo, você pinta. Vamos ver quem tem mais tinta?".

\section{Referências bibliográficas}

ACP. - Associação Comercial do Paraná. Rua são Francisco ganhou cor $e$ arte neste domingo. 2013. Disponível em: <http://www.acpr. com.br/ site/2013/06/rua-sao-francisco-ganhou-cor-e-arte-neste-domingo/>. Acesso em 30 jan. 2015.

ALMEIDA, Jorge. A relaçâo entre mídia e sociedade civil em Gramsci. Revista Compolítica, 2011. Disponível em: <http://compolitica.org/ revista/index.php/revista/article/view/8>. Acesso em 20 ago 2014. 
ALMEIDA, Lenildes Ribeiro Silva. Pierre Bourdieu: a transformaçâo social no contexto de "A Reprodução". Inter-Açãa: Rev. Fac. Educ. UFG, 30 (1): 139-155, jan./jun. 2005. Disponível em: <http://www.revistas.ufg.br/ index.php/interacao/article/view/1291>. Acesso em 20 ago 2014.

BANKSY. Guerra e spray. Rio de Janeiro: Intrínseca, 2012.

BENJAMIN, Walter. A obra de arte na época de sua reprodutibilidade técnica. In: ADORNO et al. Teoria da Cultura de massa. Trad. de Carlos Nelson Coutinho. São Paulo: Paz e Terra, 2000. p. 221-254.

BRAGA, José Luiz. Experiência estética \& mediatização. In: LEAL, Bruno S.; MENDONÇA, Carlos; GUIMARÃES, César G. (Orgs.). Entre o sensível e o comunicacional. Belo Horizonte: Autêntica, 2010.

BRASIL. Constituição da República Federativa do Brasil. Lei no 9.605, de 12 de fevereiro de 1998. Disponível em: <http://www.planalto.gov.br/ ccivil_03/LEIS/L9605.htm>. Acesso em 08 jan. 2015.

BRASIL. Constituição da República Federativa do Brasil. Lei no 12.408, de 25 de maio de 2011. Disponível em: <http://www.planalto.gov.br/ ccivil_03/_Ato2011-2014/2011/Lei/L12408.htm>. Acesso em 08 jan. 2015.

CANCLINI, Nestor Garcia. Culturas hibridas: estratégias para entrar e sair da modernidade. 4. ed. São Paulo: EDUSP, 2003.

Consumidores e cidadãos: conflitos multiculturais da globalização. Rio de Janeiro: Editora UFRJ, 2006.

CATUNDA, Michel. Campanha pichação é crime. Disponível em: <http:// ktunda.blogspot.com.br/2013/01/pichacao-e-crime.html>. Acesso em 08 jan. 2015.

DIDI-HUBERMAN, Georges. O que vemos, o que nos olha. São Paulo: Editora 34, 1998.

FRANCO, Sérgio Miguel. Iconografias da metrópole: grafiteiros e pixadores representando o contemporâneo. (Dissertação em Arquitetura e Urbanismo) - Universidade de São Paulo, 2009.

FREITAS NETO, Edgard da Costa. Um estudo sobre "Janelas Quebradas" $e$ "Tolerância Zero". 2007. Disponível em: <http://pt.scribd.com/ doc/108032115/Um-estudo-sobre-Janelas-Quebradas-e-ToleranciaZero\#scribd>. Acesso 15 jan. 2015.

GUIMARĀES, César G.; LEAL, Bruno S. Experiência mediada e experiência estética. Anais da XVI COMPÓS. Curitiba: Universidade 
Tuiuti do Paraná, 2007. Disponível em: <http://www.compos.org.br>. Acesso em 01 fev. 2015.

HALL, Stuart. Da diáspora: identidades e mediaçôes culturais. Belo Horizonte: Editora UFMG, 2003.

MARTIN-BARBERO, Jesus. Dos meios às mediaçôes: comunicação, cultura e hegemonia. Rio de Janeiro: UFRJ, 1997.

OLIVEIRA, Cecília. Grafite, polícia e ordem pública. Abordagem policial. 19 dez. 2013. Disponível em: <http://abor dagempolicial.com/2013/12/grafitepolicia-e-ordem-publica/\#.VK7VmWOGe81>. Acesso em 08 jan. 2015.

OLIVEIRA, José Geraldo. Grafitecidade e visão travelar - comunicação visual, rebeldia e transgressão. Dissertação de mestrado. Orientação profa. Dra. Dulcília Helena Schroeder Buitoni. Casper Líbero, Sáo Paulo, 2012.

RÁDIO98FM Curitiba, 2014. ACP pichação - Zé Sujeira. Disponível em: <https://www.youtube. com/watch?v=jBGt5Kym_T4 >. Acesso em 08 jan. 2015.

RÁDIO PREFEITURA. Personagem ZéSujeira será destaque da campanha deste ano (áudio). Disponível em: <http://www.curitiba.pr.gov.br/radio/ personagem-ze-sujeira-sera-destaque-da-campanha-deste-ano/142915>. Acesso em 08 jan. 2015.

RAMOS, Murilo C.; SANTOS, Suzy dos. (Orgs.). Políticas de comunicação: buscas teóricas e práticas. São Paulo: Paulus, 2007.

SÃO PAULO. Prefeitura de São Paulo. Cidade limpa: uma São Paulo melhor pra gente! Disponível em: <http://ww2.prefeitura.sp.gov.br/cidadelimpa/ conheca_lei/conhe ca_lei.html>. Acesso em 08 jan. 2015.

SCREMIN, L. GASPARIN, M. Documentário "Expressão da Rua”. 2014. Disponível em: <https://www.youtube.com /watch?v=BMQo5Hh3Q7g>. Acesso em 13 jan. 2015.

SEED/PR - Secretaria da Educação do Estado do Paraná. Poluição visual. Disponível em: <http://www.geografia.seed.pr.gov.br/modules/galeria/ detalhe.php?foto=878\&evento=7>. Acesso em 14 jul 2015.

SOARES, Flávia Cristina. Pixação em Belo Horizonte: identidade e transgressão como apropriação do espaço urbano. Revista Ponto Urbe. Ano 6. Dez, 2012. Disponível em: <http://www.pontourbe.net/edicao12artigos/274-pixacao-em-belo-horizonte-identidade-e-transgressao-comoapropriacao-do-espaco-urbano>. Acesso em 08 jan. 2015.

TX-PUBLITEX. Publicases, 2013. Disponível em: <http://www.tx.com. br/cases? page $=1>$. Acesso em 08 jan. 2015. 


\section{Notas}

1. Bansky é o pseudônimo de um artista de rua britânico. Seus trabalhos, em estêncil, podem ser encontrados em diversas cidades do mundo. Tem sido divulgado que a verdadeira identidade do artista é Robin Gunningham. Disponível em: <http:// www.thedailybeast.com/articles/2016/03/11/the-secret-life-of-the-real-banksyrobin-gunningham.html>. Acesso em 14 abr. 2016.

2. BRASIL. Constituição da República Federativa do Brasil. Lei no 12.408 , de 25 de maio de 2011. Disponível em: <http://www.planalto.gov.br/ccivil_03/_Ato20112014/2011/Lei/L12408.htm>. Acesso em 08 jan. 2015.

3. Disponível em: <http://www.planalto.gov.br/ccivil_03/_Ato2011-2014/2011/ Lei/L12408.htm>. Acesso em 14 jul. 2015.

4. VEJA SÁO PAULO. Prefeitura apaga parte de grafite da dupla Os Gêmeos. 2013. Disponível em: http://vejasp.abril.com.br/materia/prefeitura-apaga-grafite-osgemeos. Acesso em 08 já. 2015.

5. SÃO PAULO. Prefeitura de São Paulo. Cidade limpa: uma São Paulo melhor pra gente! Disponível em: <http://ww2.prefeitura.sp.gov.br/cidadelimpa/conheca_lei/ conheca_lei.html.> Acesso em 08 jan. 2015.

6. PARANÁ. Prefeitura de Curitiba. Pichação é crime. Disponível em: < http:// www.curitiba.pr.gov.br/ noticias/entra-em-vigor-a-lei-que-aumenta-multa-parapichadores-em-curitiba/31561>. Acesso em 12 jan. 2015.

7. MOFOLANDIA. Sujismundo. 2002. Disponível em: < http://www.mofolandia. com.br/>. Acesso em 08 já. 2015.

8. DANIDRAWS. 50 Facial Expressions and How to Draw Them. Disponível em: $<$ danidraws.com/bl og/2007/12/06/50-facial-expressions-and-how-to-drawthem/>. Acesso em 08 jan. 2015.

9. DREAMSTIME. Bandido dos desenhos animados que guardara uma arma. Disponível em: <http:// pt.dreamstime.com/imagem-de-stock-royalty-free-bandido-dos-desenhosanimados-que-guardara-uma-arma-image31242176>. Acesso em 08 já. 2015.

10. VERGAL, S. A desordem e a teoria das janelas quebradas. 2013. Disponível em: $<$ http://eduardo cabette.jusbrasil.com.br/artigos/121937294/a-desordem-e-ateoria-das-janelas-quebradas>. Acesso em 13 jan. 2015.

11. ACP. Rua são Francisco ganhou cor e arte neste domingo. 2013. Disponível em: $<$ http://www.acpr. com.br/site/2013/06/rua-sao-francisco-ganhou-cor-e-arteneste-domingo/>. Acesso em 30 jan. 2015.

12. RIEGER, T. Projeto vai criar galeria a céu aberto no Sáo Francisco. 2013. Disponível em: <http://www.gaze tadopovo.com.br/vidaecidadania/despiche/ conteudo.phtml?id=1383612>. Acesso em 30 jan. 2015.

13. CANEPA, L. Artistas fazem despiche da Rua São Francisco: arte substitui pichações nas portas das lojas do comércio local. 2013. Disponível em: <http://www. 
gazetadopovo.com.br/vidaecidadania/despiche/conteudo.phtml ?id=1384706>. Acesso em 30 jan. 2015.

14. CANEPA, L. Despiche chega à rua São Francisco. 2013. Disponível em: <http://www.gazetadopovo.com.br/vidaecidadania/despiche/conteudo. phtml?id=1384824>. Acesso em 30 jan. 2015.

15. MARCHIORI, R. Grafite vence a pichação e propicia galeria a céu aberto. 2013. Disponível em: <http://www. gazetadopovo.com.br/vidaecidadania/despiche/ conteudo.phtml?id=1387527\&tit=Grafite-vence-a-pichacao-e-propicia -galeria-aceu-aberto>. Acesso em 30 jan. 2015. 